\title{
Reforming the NHS: necessary and achievable?
}

\begin{abstract}
A NEW NHS
Proposals for radical NHS reform by the UK's Secretary of State for Health provoked such a storm of protest and concern that the prime minister appeared on breakfast television and, on the same day, published an opinion piece in The Times newspaper to defend them. ${ }^{1}$ By this point, the rationale for reform had mutated into a combination of saving money and simultaneously improving health outcomes - both of which have to be achieved in the context of changing demography and disease epidemiology, rampant technology, rising patient expectations, and shrinking resources.
\end{abstract}

\section{THE CASE FOR REFORM}

The reforms were needed, the government claims, because we are performing worse than many of our European neighbours. The data used to make this case, however, are a couple of years old and the claims of inferior 'amenable mortality'2 have since been challenged. Appleby has shown that UK health outcomes for heart disease, for example, have now almost converged with those in France - where outcomes are reckoned to be good - and at lower cost. ${ }^{3}$ Similar trends are apparent for lung cancer. Cooper et al have documented that waiting times for knee, hip, and cataract surgery have greatly improved, without any evidence of widening health inequities. ${ }^{4}$ Access to diagnostic and treatment facilities for cancer have also improved, and there has been progress in improving access to GPs.

All this has been achieved against the adverse background of the European Working Time Directive, the unregulated employment of doctors unfamiliar with the $\mathrm{NHS}$, and serious problems with medical career structures. It seems that the investment in services and health promotion made by the previous government may still be working through the system.

Where exactly were the problems that necessitated root and branch reform? They certainly weren't foreshadowed in either of the coalition parties' election manifestos. Were there not opportunities to cut administrative waste in Whitehall, the regions, and the primary care trusts (PCTs) without dismantling the entire system? Was it not possible to learn from the experience and evidence of good and cost-effective practice to create more powerful and better informed commissioning bodies, involving GPs, specialists, and public health experts, to design more integrated care pathways? Hadn't the obsession with patient choice run its course, when all that doctors and patients want is the certainty of being able to find effective and safe services?

\section{MAJOR CONCERNS}

Given the length of their gestation, many commentators have been astonished at how half-baked the proposals are, how rushed their publication, and how clumsy their treatment of the very professionals that the government must rely on to run the service. Little wonder that, as their implications have gradually crystallised, opposition has mounted. Severe criticism has come from the editors of both the British Medical Journal ${ }^{5}$ and The Lancet, ${ }^{6}$ and concerns have also been expressed by The King's Fund, ${ }^{7}$ the Nuffield Trust $^{8}$ and, tellingly, the National Audit Office, whose National Health Service Landscape Review ${ }^{9}$ warned of the dangers to service quality posed by distracting GPs from clinical work with the demands of commissioning.

These untested reforms are proceeding much too quickly, whereas an iterative approach would enable lessons to be learned from the early adopters and pathfinders. They are likely to be very expensive - NHS reforms always are and the uncertainty about management arrangements for the consortia may already have driven talent out of NHS management. The requirement for high- quality management, shown to be a key factor in a recent study of US health systems, has been emphasised in the Nuffield Trust report. ${ }^{8}$

The 'any willing provider' model will, inevitably, mean duplication of services, competition based on price rather than quality - which has never been shown to reduce health service costs - and, with the opening up of healthcare boundaries, perverse incentives driving patient flows. Opportunities for collaboration between primary and secondary care, an Achilles heel of the NHS, have been squandered and there are real concerns that the new system will exacerbate, rather than ameliorate, health inequalities because more developed practices, which tend to be located in more affluent areas, and their more articulate patients will be able to work the system better than those practicing in areas of deprivation.

The Health and Social Care Bill has to be read alongside other key policy documents, not least Liberating the NHS: Developing the Healthcare Workforce ${ }^{10}$ which proposes a similar radical overhaul of the ways in which healthcare professionals are educated and trained and how their education and training will in future be funded. This paper contains worrying implications for medical schools, universities, deaneries, heath research, and the quality of education and training supported by new providers of NHS services. The implementation of the Browne review ${ }^{11}$ of the funding of higher education will have an impact here too.

\section{MAKING IT WORK}

Despite all this, GP consortia are beginning to form, PCTs are starting to metamorphose into supporting management structures, and the Royal College of General Practitioners is setting up a centre to support commissioning. How can this seemingly inevitable policy direction be made to work most constructively? First, slow down. Rather 
than compelling all GPs to be in the consortia by a fixed and premature date, allow the system to develop iteratively. Second, gather evidence and learn. This doesn't mean more long-winded health services research but an awareness of what works and what doesn't, and a willingness to share good practice and to avoid the repetition of bad decisions. Third, collaborate: the 'GPs know best' mantra is pretty hollow, and we need to work with specialist colleagues to identify needs and plan better services. Where primary-secondary care relationships are good, build on them. Where they are less good, support and improve them through some form of joint planning and commissioning. Fourth, be vigilant for changes that prioritise costs over quality, exacerbate inequalities, and divert educational resources into service funding.

Above all, strengthen primary care: avoid eviscerating general practice by trying to turn talented clinicians into medical managers; prepare the GPs of the future even better for the complexities of practice by extending the duration and scope of vocational training; get rid of gimmicks such as walk-in centres; discourage fragmentation of personal care; and reassert the values of organisational continuity and team care. And remember
Don Berwick's wise words about general practice and primary care: 'These, not hospital care, are the soul of a proper, community-oriented, health-preserving care system' ${ }^{12}$

\section{Roger Jones,}

Editor, British Journal of General Practice.

\section{Provenance}

Freely submitted; not peer reviewed.

\section{REFERENCES}

1. Cameron D. The NHS will sicken unless we modernise [opinion]. Times 2010; 31 Jan: 20.

2. Department of Health, Medical Directorate, Quality and Outcomes Policy. Transparency in outcomes: $a$ framework for the NHS. London: Department of Health, 2010.

3. Appleby J. Data briefing: does poor health justify NHS reforms? BMJ 2011; 342: doi:10.1136/bmj.d566.

4. Cooper ZN, McGuire A, Jones S, Le Grand J. Equity, waiting times and NHS reforms: retrospective study. BMJ 2009; 339: doi:10.1136/bmj.b3264.

5. Delamothe T, Godlee F. Dr Lansley's monster. BMJ 2011; 342: doi: 10.1136/bmj.d408.

6. Horton R. No, Mr Cameron, you are peddling myths about NHS reform [letter]. The Times 2011; Feb 1: 25.

7. The King's Fund. The King's Fund comments on the publication of the Health and Social Care Bill. http://www.kingsfund.org.uk/press/press_releases/the kings_fund_32.html (accessed 11 Feb 2011).

8. Thorby R, Rosen R, Smith J. GP commissioning: insights from medical groups in the United States. London: Nuffield Trust, 2011.

9. National Audit Office. National Health Service Landscape Review. London, National Audit Office 2011

10. Department of Health. Liberating the NHS: developing the healthcare workforce. London: HMSO, 2011.

11. Browne J. Securing a sustainable future for higher education: an independent review of higher education funding and student finance.

http://www.bis.gov.uk/assets/biscore/corporate/docs/s/1 0-1208-securing-sustainable-higher-education-brownereport.pdf (accessed 11 Feb 2011).

12. Berwick DM A transatlantic review of the NHS at 60 BMJ 2008; 337: doi: 10.1136/bmj.a838.

DOI: 10.3399/bjgp11X561096
ADDRESS FOR CORRESPONDENCE

\section{Roger Jones}

Editor, British Journal of General Practice, Royal College of General Practitioners, 1 Bow Churchyard, London EC4 9DQ.

E-mail: rjones@rcgp.org.uk 